Edyta Krzysztofik, LL.D.*

Associate Professor, Department

of European Union Law,

Faculty of Law, Canon Law and Administration,

John Paul II Catholic University of Lublin, Poland
ОРИГИНАЛНИ НАУЧНИ РАД

doi:10.5937/zrpfni1879157K

UDK: $341.231(4-672 E U)$

Рад примљен: 30.09.2018.

Рад прихваћен: 02.11.2018.

\title{
THE PRINCIPLE OF RESPECT FOR THE MEMBER STATES' NATIONAL IDENTITY WITH REGARD TO THE RIGHTS AND OBLIGATIONS OF MIGRANT CITIZENS OF THE EUROPEAN UNION**
}

\begin{abstract}
The principle of respect for the national identities of the Member States is directed principally at the Member States and defines the relationship between the Member States and the European Union. The conceptual scope of the principle itself includes two levels: ethical and institutional. The first covers such elements as history, culture, tradition, language and religion. The other is connected with the constitutional identity of a Member State.

The principle of respect for national identity is first of all used in the context of restrictions on the effectiveness of EU law in the legal systems of the Member States. These States can invoke one of the elements shaping the national identity in order to,for example, limit the freedoms of the Internal Market. It should be emphasized that the limiting conditions include not only the ethical space, but also the institutional one, e.g.the protection of human rights or a threat to public order. Secondly, respect for national identity in the institutional space, as constitutional identity, is a basic argument in the discussion on the exclusive competences of Member States and the preservation of sovereignty by the Member States.
\end{abstract}

\footnotetext{
*ekrzyszt@kul.pl

${ }^{* *}$ This paper was presented at the International Scientific Conference "Law in the context of addressing the Challenges of the Contemporary World", held at the Faculty of Law, University of Niš, on $13^{\text {th }}-14^{\text {th }}$ April 2018.
} 
In the context of the rights of migrant citizens of the European Union, it seems that the impact of the discussed principle is limited. The catalog of citizen rights does not refer directly to this principle. As has been shown above, the solution is to invoke the prohibition of discrimination based on origin, which can effectively protect the national language, religion or other elements shaping the national identity of the country of origin. However, this view is not entirely right. In the Avello case the Court of Justice referred to a problem that exceeded the competence of the European Union and ruled on matters falling within the exclusive competence of the Member States. The Court decided that attribution of family name to children with dual citizenship in accordance with the tradition and culture of the migrant's country of origin has higher value than division of competences.

The principle of respect for the national identity of the Member States indirectly affects the obligations of a migrant citizen to the host country. It is not possible to accept the thesis that it is a civic duty, but in certain areas it shapes indirectly the obligations of a migrant citizen to a Member State. The citizen is obligated to respect the order, security and public health of the host country. The consequence of violation of this obligation is expulsion from the host state's territory or refusal to grant the right of residence.

Key words: the principle of respect for the national identities of the Member States, rights of migrant citizens, obligations of migrant citizens, citizenship, limitation of residence rights of migrant citizens.

\section{General remarks}

The European Union is an international organization that assumes the establishment of an internal market as one of the basic objectives, including guaranteeing the free movement of EU citizens. This freedom has been shaped from the beginning of the EC's existence to the present day. Initially, it was associated with the economic activity of migrant citizens of the Member States. After the entry into force of the Maastricht Treaty and the establishment of EU citizenship, this freedom acquired a different character, and the freedom of movement became a civil right, which is implemented without the obligation to indicate the economic activity of a migrant citizen in the host country.

A separate issue is the status of a migrant citizen in the territory of the host country. The Treaties and the Charter of Fundamental Rights (CFR)established a catalogue of civil rights. It is a catalogue that can be extended by EU law-making institutions. The obligations of migrant citizens have not been established yet but the Treaties provide for this possibility. 
The subject of this article is the analysis of the impact of the principle of respect forthe national identities of the Member States on the scope of rights and possibly obligations of EU citizens. It covers three elements: firstly, the political position and the content of the principle of respect forthe national identity of the Member States; secondly, the jurisprudence of the $\mathrm{CJ}$ in the context of respect for the national identity of migrant citizens; and thirdly, an attempt will be made to show that each migrant citizen has the obligation to respect the national identity of the host country and that in this sense it is a civic duty.

\section{The principle od respect for national identity}

The concept of "national identity" is generally associated with nation and its special features. The nation should be understood as a social group inhabiting a specific area, characterized by common geographical origin, religion, language, dialect, tradition, values, symbols, legal system, etc. There is the view in the literature on the subject that "national identity" is a "set of elements - treated by the nation as common to it - that bind it" (Mik, 2000:465). For the state, it will be "the awareness of having national and state characteristics, identifying with them, as well as the feeling of unity with other members (entities) of this community" (Kuchciński, 2011:37). Thus, it should be assumed that identity is treated as a set of elements that constitute a nation. These include: material culture, language and spiritual culture. However, it is worth paying attention to the broader concept of national identity, which does not limit itself to the indicated elements, but also emphasizes the "obligation to respect the continuity of existence of the Member States as sovereign subjects, respect for national cultures, standards of family law, rules defining the State-Church relations, languages (official), the means of providing access to state social security" (Wójtowicz, 2011: 6).

The literature on the subject indicates two dimensions of the concept of national identity: institutional and ethical. The first refers to the state system; the second refers to the structure of fundamental rights and the rule of law. Each state is based on values that can be specific to a given state and closely related to the culture of a given society(Arnold, 2009: 56 - 58). In addition, it is emphasized that national identity is a cultural unity and the will to belong to a given country. At the same time, cultural unity means a specific culture, language, customs, religion, while the second aspect refers to the basic functions of the state that determine its legal autonomy (Wójtowicz, 2010: 12).In one of the commentaries on the Treaty on European Union, one may also find a definition of this concept based on two areas. One is, among others, the specificity of culture, language, customs and religion; the other one is state autonomy and the preservation of basic state functions (Mik, Czapliński, 2005: 57). 
To sum up the indicated exemplary views on the content of the term "national identity", one should recognize two dimensions: ethical (culture, language, customs, religion) and institutional, related to the basic functions of the state.

\subsection{The principle of respect for the national identity in EU law}

The principle of respect for national identity was introduced for the first time to the provisions of the Treaty of Maastricht. According to the Treaty on European Union of 1991, "The Union shall respect the national identities of its Member States, whosesystems of government are founded on the principles of democracy." Successive treaties strengthened its significance. The Treaty of Lisbon specified the content of the principle by introducing a reference to the basic political and constitutional structures of the state, including regional and local self-government (Art. 4 par. 2 Treaty on European Union).A partial reference to the scope of the concept of national identity has been emphasized in the Preamble to the Treaty on European Union. In accordance with its provisions, the Union's aim is to deepen solidarity between its nations while respecting their history, culture and traditions. Another document with a normative value equal to primary law, in which there is a partial reference to the principle of respect for the national identity of the Member States, is the Charter of Fundamental Rights (hereinafter referred to as the CFR). According to the wording of the Preamble(Para 3), "The Union contributes to the preservation and to the development of these common values while respecting the diversity of the cultures and traditions of the peoples of Europe as well as the national identities of the Member States and the organisation of their public authorities at national, regional and local levels." Moreover, "The Union shall respect cultural, religious and linguistic diversity"(Art. 22 CFR).The above-mentioned provisions focus primarily on the concept of national identity in the context of diversity of cultures and traditions of the peoples of Europe. They point to the European Union's reliance on individual, diverse states that have their own distinctiveness and which are characterized by their own culture and tradition. It is a kind of added property of the entire European Union.

\subsection{The principle of respect for national identity in the case-law of the Court of Justice}

Changes introduced by the Treaty in the context of the principle of respect for the national identity of the Member States developed under the influence of the case-law of the Court of Justice. It emphasized repeatedly that the EU "[...] is to respect the national identities of its Member States[...]" (C 208/09) and that it is "... a legitimate aim respected in the Community legal order ..."(C 473/93). It is also worth making a reference to the Opinion delivered by the Advocate General 
Maduro, who emphasized that "a Member State may, in certain cases and subject, evidently, to review by the Court, assert the protection of its national identity in order to justify a derogation from the application of the fundamental freedoms of movement" (Opinion in case C 213/07).

The analysis of judgments of the Court of Justice shows that it has repeatedly recognized individual elements shaping the content of the concept of national identity, e.g. protection of the language of a Member State (C 379/78 Groener), protection of history, tradition and culture (C 154/89, C 180/89, C 198/89), protection of public morality (C 34/79, C 121/85), as the basis for restricting the freedoms of the Internal Market. It should be emphasized that the Court of Justice also referred to the second, institutional aspect of national identity. The limiting factor in this case is respect for constitutional identity (Krzysztofik, 2017: 155-170; Cloose, 2016:82-89).The main issue, being the subject of the case-law of the Court of Justice in the discussed context, was the conflict between the protection of the constitutional catalog of fundamental rights and the implementation of the freedoms of the Internal Market (C 112/00, C 36/02). In addition, the violation of constitutional identity is related to the problem of a threat to public order and security (C 36/02).

A separate issue, which is also directly connected with the principle of respect for national identity but in the institutional aspect, is the protection of exclusive competences of Member States. As an international organization, the European Union has competences that have been delegated to it by the Member States. The principle of conferral determines its scope of activities. The indicated problem has been the subject of a long-standing discussion between the Court of Justice and Constitutional Courts of the Member States (Krzysztofik 2014: 7-30; Pal, 2012: 316-318; Biernat, 2011:49- 61; Mikłasiewicz, 2005; Banaszak 2003).

\section{The rights of migrant citizens of EU}

Citizenship of the European Union was established in 1992 under the Maastricht Treaty. In accordance with the provisions of the Treaty, it is of a dependent nature and is derived from national citizenship (Pal, 2016: 77-78).Member States have exclusive competence in granting of their own citizenship, while the European Union and other Member States are required to recognize the legal effects of citizenship granted.(Rogers, 2005: 62-65). Citizenship of the European Union is effective for citizens of the Member States in three areas. First of all, it is a legal bond connecting the European Union and the citizens of the Member States (Wollenschläger, 2010: 3).Secondly, it is the source of citizen rights.Thirdly, having EU citizenship is the basis for exercising the freedoms of the Internal Market (Grzeszczak, 2017: 13-27). 
Considerations in this part of the article will onlybe limited to the issue of the rights of migrating citizens of the European Union, that is, what they are entitled to when using the freedom of migration. These are citizen rights whose catalog has been normalized in two ways: originally in the founding Treaty (Art. 20-24 The Treaty on the Functioning of the European Union), and later in the Charter of Fundamental Rights (Art. 39 - 46).

Pursuant to the provisions of the Treaty on the Functioning of the European Union (hereinafter referred to as the TFEU) and the CFR, a citizen of the European Union enjoys the right to migrate (Art. 21), passive and active electoral rights in the territory of the receiving state in elections to local authorities (Art. 22 par. 1) and in elections to the European Parliament (Art. 22 par. 2), uses diplomatic and consular protection in the territory of a third state when his country of origin does not have a diplomatic mission (Art. 23), he has been granted the right to petition the European Parliament (Art. 24), the right to complain to the Ombudsman (Art. 24), the right of legislative initiative (Art. 24) and the right of access to documents (Art. 24). The Charter of Fundamental Rights enriches the presented catalog with the right to good administration (Art. 41). The rights indicated above do not refer to respect for the national identity of the Member States. The subject of considerationsis the rights of citizens of the European Union, which refer to their national identity, which is directly related to the national identity of the Member State of their origin. A specific reference can be found in the CFR's resolutions (Articles 10, 13, 14, 22).As emphasized above, it refers to some aspects of national identity, especially in the ethical dimension. However, it should be remembered that the CFR refers to the EU's approach to specific values, and does not protect national identity in an individual sense.

From the perspective of the implementation of the principle of respect for the national identities of the Member States with regard to therights of citizens, the importance of the prohibition of discrimination on grounds of origin should be emphasized. According to the wording of the TFEU and the CFR, all discrimination on grounds of nationality (Art. 18)as well as on grounds of gender, race or ethnic origin, religion or belief, disability, age or sexual orientation is forbidden. The indicated provisions, on the one hand, introduce a general prohibition of discrimination and detailed premises of prohibited differentiation. However, it should be borne in mind that the provisions of the CFR are only applied within the scope of European Union competences and bind Member States in the implementation of EU law (Art. 51);thereby, certain aspects that shape national identity are limited to the scope of the European Union competences.

An example of invoking the prohibition of discrimination in the context of the protection of certain aspects of the national identity of a migrant citizen is the 
position of the Court of Justice on matters concerning the use of the official language of the country of origin before the authorities of the host country, if national law provides for the possibility of derogating from the obligation to use the language of the host country in certain circumstances. The Court of Justice emphasized that "Although, generally speaking, criminal legislation and the rules of criminal procedure such as the national rules in issue, which govern the language of the proceedings are matters for which the Member States are responsible, the Court has consistently held that Community law sets certain limits to their power in that respect. Such legislative provisions may not discriminate against persons to whom Community law gives the right to equal treatment or restrict the fundamental freedoms guaranteed by Community law"(C 274/96).

Another example is respect for the religion of a migrant citizen. The Court of Justice addressed this problem with regard to job contests in the EU institutions, stating that institutions should avoid organizing them on the dates of religious holidays celebrated by the candidates. Ultimately, however, the interested party has the obligation to submit objections to the proposed dates (C 130/75).

\section{The impact of the principle of respect for the national identities of Member States on the rights of migrating citizens}

In order to demonstrate the impact of the principle of respect for the national identities of the Member States on the rights of a migrant citizen, reference should be made to the judgment of the Court of Justice in the Avello case. The subject matter was the situation of a Spanish citizen being a migrant worker in Belgium. He requested to change the last name of his children, who received it in accordance with the rules of Belgian law. The facts of the case were extremely problematic because attribution of family names belongs to the exclusive competence of the Member States,in which the EU has no right to interfere. In its considerations on the prohibition of discrimination, the Court stated that "It is in this regard settled case-law that the principle of non-discriminationrequires that comparable situations must not be treated differently and thatdifferent situations must not be treated in the same way [...] Such treatment may be justified only if it is based onobjective considerations independent of the nationality of the persons concerned and is proportionate to the objective being legitimately pursued [...]" (C 148/2). When making a direct reference to the fact, the Court recognized that "Articles 12 EC and17EC must be construed as precluding, in circumstances such as those of the case in the main proceedings, the administrative authority of a MemberState from refusing to grant an application for a change of surname made on behalf ofminor children resident in that State and having dual nationality of that State and ofanother Member State, in the case where the purpose of that 
application is to enablethose children to bear the surname to which they are entitled according to the law andtradition of the second Member State" (C 148/2). The Court of Justice found that children with dual citizenship have the right to be named in accordance with the law and traditions of the other Member State. The Court stated that respect for the law and traditions of the country of origin is a derived right of a migrant citizen.

\section{Limiting the residence rights of migrant citizens due to the threat to public order and security and the obligation to respect the constitutional identity of the host country}

The issue concerning the obligations of migrant citizens is more difficult. The authors of the Treaties have not established any civic obligations, although this is not excluded because the Treaties provide for such a possibility in the future. While referring tomigrant citizens, one should consider their position on the territory of the host country. By crossing the host country's borderthey enter into the legal, social and cultural order of the receiving state.The Treaties do not indicate obligations to the host country, but they define three derogation clauses: breach of public order, breach ofsecurity, and protection of public health. Their fulfilment may lead not only to the refusal to grant the right of residence but also to the expulsion of migrant citizens from the territory of the receiving state. In its rulings, the Court of Justice emphasized that the obligations imposed on Member States may also constitute rights of individuals expressed in a negative way. It seems that such a methodology can also be adopted in this situation. The provisions of Article 45 par. 2 TFEU are not only the derogatory conditions but also the obligation of a migrant citizen to respect order, safety and public health. This obligation is also strengthened by the implementation of one of the most important principles of public international law - the principle of supremacy of the nation.

The most important issue here is to define the concept of respect for public order and security, which seem to be crucial from the perspective of national identity.

According to the established case law of the Court of Justice, this concept means that " $a$ threat to the functioning of institutions and essential public services and the survival of the population, as well as the risk of a serious disturbance to foreign relations or to peaceful coexistence of nations, or a risk to military interests, may affect public security." Therefore, it should be assumed that from the perspective of a migrant citizen there is an obligation to respect certain values and institutions that constitute the legal heritage of the host country. This refers to respect for the institutional dimension of national identity and, more precisely, constitutional identity. However, the Court of Justice also pointed to some ethical 
aspects, such as public morality, culture or religion, but always in the context ofviolation of public order.

\section{Conclusions}

1. The principle of respect for the national identity of the Member States is addressed directly to the European Union and the Member States. In the first case, it is connected with the obligation to respect the diversity of the Member States in the process of establishing EU law.On the other hand, in the case of the Member States, it means the right to oppose the effectiveness of EU law in a situation where it violates the national identity of the Member States. At this point, the judgment in the Omegacase should be cited as an example, where the constitutional obligation to respect human dignity was grounds for restriction of the free movement of services; protection of national heritage, culture and art -the problem of tourist guides in the cases of the Commission vs France, the Commission vs Italy or the Commission vs Greece; or the national language of the state - the Groener case - protection of the Irish language. In each of these cases, the $\mathrm{CJ}$ recognized the right of a Member State to restrict the freedoms of the internal market.

It should also be remembered that this principle has a second dimension which refers directly to the scope of competences conferred to the European Union. This problem has been widely commented on in the rulings of the Constitutional Courts of the EU Member States. The judgments which were made after the entry into force of the Treaty of Lisbon indicate the scope of non-transferable competences that are the exclusive competence of the Member States.

To summarise, each Member State defines the notion of national identity and its scope, which remain inseparably connected with the state's history, tradition and the achievements.

2. The principle of respect for the national identity of the Member States indirectly affects the scope of the rights of a migrant citizen. There are no grounds for accepting the thesis that respect for national identity is a civil right, although there is no doubt that it derives from EU citizenship. Every EU citizen has the right to equal treatment and any discrimination on grounds of national origin is forbidden. Thus, individual elements shaping his identity will be protected. The analysis of case law points, for example, to respect for national traditions manifested through the right to name children in accordance with the rules of the country of origin (the Avello case), or the right to use the language of the state of origin in the courts of the host country (the Unker case). 
On the other hand, EU law and the Charter of Fundamental Rights form the basis for the protection of individual rights of EU citizens, not necessarily in the aspect of migration, such as the prohibition of discrimination on the basis of faith, religion or belief. However, it should be remembered that a citizen can only rely on the CFR with regard to EU competences and when Member States implement EU law.

3. The principle of respect for the national identity of the Member States indirectly affects the obligations of a migrant citizen to the host country. It is not possible to accept the thesis that it is a civic duty, but in certain areas it shapes indirectly the obligations of a migrant citizen to a Member State. The citizen is obligated to respect the order, security and public health of the host country. The consequence of violation of this obligation isexpulsion from the host state's territory or refusal to grant the right of residence. This has been confirmed in many judgments of the Court of Justice, e.g. the refusal to grant the right of residenceto people who violate public morals or public order by belonging to terrorist organizations.

\section{References}

Arnold, R. (2009). Tożsamość narodowa i ponadnarodowa w Traktacie z Lizbony. In: Piontek E. Karasiewicz, K. (ed.). Quo Vadis Europo III?. Warszawa.

Banaszkiewicz B. (2003). Węzłowe problemy w orzecznictwie Trybunału Sprawiedliwości Wspólnot Europejskich, Biuro Trybunału Konstytucyjnego, Zespół orzecznictwa i studiów,http://www.trybunal.gov.pl/epublikacje/download/ Trybunal_sprawiedliwosci.pdf

Biernat S. Zasada pierwszeństwa prawa unijnego po Traktacie z Lizbony. Gdańskie Studia Prawnicze. vol. XXV.

Cloots E. (2016). National Identity, Constitutional Identity, and Sovereignty in the $E U$, Netherlands Journal of Legal Philosophy (45) 2.

Grzeszczak R. (2017). The Citizenship of the European Union and the Free Movement of Workers or There and Back Again. Krzysztofik E. (ed.). Personal Freedoms of the Internal Market of the European Union in the Light of the Changing Political and Economical Situation in Europe. Berlin.

Krzysztofik E. (2017). The Position of the Principle of Respect for Constitutional Identity in EU Law, Przegląd Prawa Konstytucyjnego. 6 (40).

Krzysztofik, E. (2014). Charakter prawa unijnego w orzecznictwie Trybunału Sprawiedliwości i sq̨dów konstytucyjnych państw członkowskich, Roczniki Nauk 
Prawnych, no. 2, vol. XXIV. pp. 7 - 30.Pal, R. M. (2012). Charakter prawa Unii Europejskiej. In: Kuś (ed.). A. Prawo instytucjonalne Unii Europejskiej, Lublin.

Kuciński, J. (2011). Unia Europejska jako wspólnota państw i narodów po wejściu $w$ życie traktatu z Lizbony, Studia Prawnicze i Administracyjne. 1 (2).

Mik, C. (2000). Europejskie prawo wspólnotowe, zagadnienia teorii i praktyki, Warszawa.

Mik, C. Czapliński, W. (2005). Komentarz do TUE. Warszawa.

Mikłasiewicz P. (2005). Zasada pierwszeństwa w krajowych porzadkach prawnych według orzecznictwa ETS i Sądu I Instancji, Biuro Trybunału Konstytucyjnego, Zespół orzecznictwa i studiów. Retrieved from: URL=http://www.trybunal.gov. pl/epublikacje/download/PIERWSZENSTWO.pdf;

Pal R. M. (2016). Obywatelstwo Unii Europejskiej a problem migracji. In: Krzysztofik E. Pal R.M. (ed.). Prawno-historyczne uwarunkowania migracji Polaków po II wojnie światowej, w okresie solidarnościowym i po akcesji do Unii Europejskiej. Lublin.

Rogers N. Scannell R. Walsh, J. (2005). Free Movement of Persons in the Enlarged European Union, London.

Wollenschläger F. (2010). Obywatelstwo UE i jego dynamika dla procesu integracji poza wymiarem rynkowym, Europejski Przegląd Sądowy. no 6.

Wójtowicz, K. (2010). Poszanowanie tożsamości konstytucyjnej państw członkowskich Unii Europejskiej. Przegląd Sejmowy. 4(99).

Wójtowicz, K. (2011). Zachowanie tożsamości konstytucyjnej państwa polskiego w ramach UE - uwagi na tle wyroku TK z 24.11.2010 r. (K 32/09).EPS XI.

Legal documents

Charter of Fundamental Rights of the European Union, Official Journal of the EuropeanUnion, C 326 of 26 October 2012.

Treaty on European Union, Commission of the European Communities, 1992; retrieved from https://europa.eu/europeanunion/sites/europaeu/files/docs/ body/treaty_on_european_union_en.pdf.

Treaty on European Union (consolidated text), Official Journal of the European Union, 2016 C 202.

Treaty on the Funtioning of the European Union, Official Journal of the European Union, C-326 of 26 October 2012. 
Treaty of Lisbon, amending the Treaty on European Union and the Treaty establishing the European Community, signed in Lisbon, 13 December 2007, Official Journal of the European Union, 2017 C306.

Case law of the Court of Justice

Case C 130/75 VivienPraisvCounciloftheEuropeanCommunities.

C 154/89 Commission of the European Communities v French Republic,

C 198/89 Commission of the European Communities v Hellenic Republic.

C 473/93Commission of the European Communities v. Grand Duchy of Luxembourg.

C 180/89 Commission of the European Communities v Italian Republic,

C-274/96 Bickel and Franz.

Case 379/87 Anita Groener v Minister for Education and the City of Dublin Vocational Educational Commitee.

C 34/79 Henn and Darby

C 121/85 Conagate limited v HM Custom\&Excise.

C 112/00 Eugen Schmidberger, Internationale Transporte und Planzüg v. Republic of Austria.

C - 36/02 Omega Spielhallen- und Automatenaufstellungs-GmbH v. Oberbürgermeisterin der Bundesstadt Bonn 1.

C-208/09 Ilonka Sayn-Wittgenstein v. Landeshauptmann von Wien.

C 391/09 Malgožata Runevič-Vardyn, Łukasz Paweł Wardyn.

Opinion of Advocate General Christine Stix-Hackl in Case C-36/02Omega.

Opinion of Advocate General Poiares Maduro in Case C 213/07 Michaniki AE v. Ethniko Simvoulio Radiotileorasis Ipourgos Epikratias Elliniki Technodomiki (TEVAE), formerly Pantechniki AE Sindesmos Epikhiriseon Periodikou Tipou. 
Др Edyta Krzysztofik, ПхД

Ванредни професор, Катедра за Право Европске уније, Факултет права, црквеног права и администрације, Католички универзитет Јован Павле ІІ у Лублину, Пољска

\title{
НАЧЕЛО ПОШТОВАЫА НАЦИОНАЛНИХ ИДЕНТИТЕТА ДРЖАВА ЧЛАНИЦА У ПОГЛЕДУ ПРАВА И ОБАВЕЗА МИГРАНАТА-ДРЖАВЉАНА ЕВРОПСКЕ УНИЈЕ
}

\begin{abstract}
Резиме
Начело поштовања националних идентитета држава чланица у погледу права и обавеза миграната-држављана Европске уније углавном је осноси на државе чланище и дефинише однос између држава чланища и Европске уније. Концептуални оквир самог принципа има два нивоа: етички и институционални. Етички ниво обухвата елементе као што су: историја, култура, традиција, језик и религија. Инситуционални ниво односи се на уставни идентитет државе чланище.
\end{abstract}

Начело поштовања националног идентитета се најпре користи у контексту увођења ограничења у погледу примене права Европске уније у правним системима држава чланица. Ове државе могу се позвати на један од елемената који обликују национални идентитет како би, на примјер, ограничиле права и слободе на унутрашњем тржишту. Треба нагласити да ограничавајус́и услови обихватају не само етичке принципе вес́ и институционалне стандарде, на пример у погледу заштите људских права или угрожавања јавног реда. Друго, поштовање националног идентитета у институционалним оквирима, као важном елементу уставног идентитета, представља основни аргумент у расправи о искључивим надлежностима држава чланица и очувању суверенитета од стране држава чланица Европске уније.

У контексту права миграната-држављана Европске уније, чини се да је утицај овог принципа ограничен. Овај принцип није експлицитно предвиђен у каталогу права грађана. Као што је вес́ речено, предвиђено решење је да грађанин може да се позове на забрану дискриминације на основу пореклу, којом се може ефективно заштитити национални језик, религија или други елементи који обликују национални идентитет земље порекла. Међутим, овакво решење није сасвим оправдано. У случају Авелло, Суд правде ЕУ се бавио питањем које превазилази надлежност Европске уније и донео одлуку о питањима која спадају у искључиву надлежност држава чланица. Суд је одлучио да додељивање породичног имена (презимена) код деце са двојним 
држављанством у складу с традищијом и културом земље порекла мигранта има вес́у вриедност од поделе надлежности.

Начело поштовања националног идентитета држава чланица индиректно утиче на обавезе држављана-миграната у земљи домаћину. Није могуће прихватити тезу да ово начело представља грађанску дужност, али у одређеним областима оно индиректно обликује обавезе држављанамиграната у држави чланищи Европске уније. Држављанин-мигрант је у обавези да поштује одредбе о јавном реду, безбедности и јавном здрављу државе домаћина. Последища кршења ове обавезе је протеривање са територије државе домаћина или одбијање да се одобри право боравка.

Кључне речи: начело поштовања националних идентитета држава чланица ЕУ, права и обавезе држављана-миграната, држављанство, ограничење права боравка држављана-миграната. 